\title{
Poverty AND PASTORAl COUNSElling: Design FOR AN EXTENSIVE RESEARCH PROJECT
}

Author:

Johan Janse van Rensburg

\section{Affiliation:}

${ }^{1}$ Department of Practical

Theology, University of the

Free State, South Africa

Correspondence to:

Johan Janse van Rensburg

e-mail:

jjvanr@yebo.co.za

Postal address:

CM van der Heverstraat

13, Langenhovenpark,

Bloemfontein, Free State,

9330, South Africa

\section{Keywords:}

poverty; extensive research; planning; participatory action research; design

\section{Dates:}

Received: 18 Mar. 2009

Accepted: 29 Sept. 2009

Published: 04 Nov. 2009

How to cite this article: Janse van Rensburg, J., 2009, 'Poverty and pastoral counselling: Design for an extensive research project', Verbum et Ecclesia 30(2), Art \#180, 8 pages. DOI: $10.4102 /$ ve.v30i2.180

\section{This article is available} at:

http://www.ve.org.za
(C) 2009. The Authors. Licensee: OpenJournals Publishing. This work is licensed under the Creative Commons Attribution License.

\section{ABSTRACT}

Poverty is arguably the most common and devastating social disease in the world. It is not, however, only a social, political or economic problem. Knowing how to respond to the calling of caring for the poor is an incredible charge for the church. It is not only a matter of Christian charity but also a matter of pastoral care. Extensive research on such a phenomenon needs careful planning and precise execution. It was therefore decided to conduct participatory action research with informed researchers. It is hoped that the input of these informed participators will help the researcher to design a methodology that will be able to dig deeper than the surface of the problem and to uncover the most important driving forces and basic needs of poverty. This article serves as an introduction to a four-year research project on poverty, financially supported by a generous bursary from the National Research Fund.

\section{INTRODUCTION}

'As old as the mountains and as wide as the sea' - this is how one could describe the phenomenon of poverty. Poverty has been with us for so long and we have grown so accustomed to its ugly face that we are in danger of not noticing or not caring about the terrible consequences of this disease. It is unimaginable to think that there is a corner of the globe where poverty in some form or another is not a destructive or disruptive force in any given society. Most probably, it is the feeling of hopelessness and the lack of knowledge and skills to make a difference that cause many people to be indifferent to the problem. But poverty creeps up on all societies and touches all communities in so many ways. We may probably assume that the problem is worsening, as more and more people are dehumanised by its destruction. It is therefore no longer possible to ignore it as 'something that is not our problem'.

This research is interested in the task of the church of Jesus Christ in general and in the possibilities for a pastoral approach to address the many aspects of the problem in particular. We dare not allow a feeling of hopelessness to cause the church to abandon all efforts to make a real difference in the lives of individuals, families and communities and in the country. Neither may we continue with well-meant efforts to offer support without really changing the status quo. Since this is a scientific research project stretching over four years, careful planning of the methodology for this research project is indispensable. The very essence and nature of poverty, however, highlight the difficulties of deciding on an approach for a workable and most fruitful research methodology and of identifying and uncovering the basic underlying driving forces, motives and dimensions of poverty. It was therefore decided to involve researchers who have already made contributions in this particular field in participatory action research. It is hoped that the knowledge and expertise of these carefully selected specialists in the field will add more perspectives on this issue and deepen the conceptualism about this phenomenon, thereby preventing the research project from subsiding into the mediocrity of generalisations.

\section{RESEARCH METHODOLOGY}

It is important to distinguish between the methodology for the whole research project and the methodology for this particular article. While the project in general will make use of a wide range of literature on the subject, the literature study should also form the foundation for a basis theory on theology and poverty in general and on pastoral theology and poverty in particular. The principles underlying scriptural references to poverty and its consequences for research were therefore investigated. In a multidisciplinary approach, meta-theoretical literature forms an important part of information. It is envisaged that qualitative research with both poverty-stricken people and with people involved in programmes of empowerment will serve as a significant source of information to come close to the people involved and to understand their experiences and needs. The research therefore moved from an investigation into poor people to a research with the participation of poor people, true to the nature of participatory action research. Besides literature on research methodology, such as the recent publication by Smith (2008), particular attention was given to the methodology on qualitative and participatory action research during the consultation of the large volume of publications in this regard.

Regarding the research for this particular article, the decision to involve informed specialists in the field was made to benefit from the many views, contributions and findings of their own research. It would, after all, be less than wise to embark on a research project such as this, pretending that nothing has been done before in terms of research or active involvement - almost like wasting time and effort to rediscover and redesign the wheel. Planning was therefore a very important prerequisite for this methodology. Babbie (1998:139) distinguished between the conceptualisation (planning) and the operationalisation (execution) of research. This article served as the planning stage for the execution of the whole research project.

Participatory action research is understood as participation in the planning of research and in the identification of the most important aspects of the problems, in this case, those problems forming the 
basis of the participants' views and findings on poverty. From these contributions, decisions will have to be made on the issues to be researched and on the systematic order in which to deal with them. This research then served as a launch article to guide the broader research project to be conducted. From the nature of and goals for this research, it is therefore to be understood that this article could not include an extensive reference to relevant literature, although some references were made. The vast volume of existing literature will be analysed in subsequent articles. The views expressed by the participants in this participatory action research furthermore served exactly the same purpose in guiding and planning the whole of the research project.

The participatory action research for this particular article was conducted in a structured way according to acknowledged methods for this type of research. The participants were chosen for their acknowledged contributions to scientific research on poverty or for their active involvement with organisations and programmes that address the many problems created by poverty. Only a small cross-section of experts was chosen out of the many available possibilities, however, since it would be difficult to give full attention to all the points of view of more than six participants in one article; it should be remembered that this was only a launching article for an extensive research project. The purpose of this article was therefore merely to acquire direction and markers for the extensive research. Expert opinions of informed researchers not accommodated in this article will most definitely be included in the extensive research that is to follow. A brief but relevant curriculum vitae for each participant is supplied in Addendum A.

Although Mouton and Marais (1989:157) advised that qualitative research should operate with a hermeneutic approach and that it therefore favours unstructured conversations, the questions here were designed to introduce the basic issues involved as they presented themselves to me. These questions were therefore not meant to create a formal structure or to inhibit the contributions of the participants but rather to serve as mini-maps (Bothma 2003:201) to ensure that certain issues would come under discussion. Most of the conversations were taped, except those with Prof. Kallie August and Prof. Stef Coetzee, as the tape recorder failed to function. The tapes of the conversations were kept for further reference. During all the conversations, careful notes were also made to ensure that the participants' points of view were reflected as precisely as possible. Johann Breed's contribution was received via e-mail, since it was not possible to conduct a personal discussion with him. In cases where personal contact in qualitative research is not possible, the strategy may be varied without jeopardising the scientific value of the research. Because qualitative research may be carried out with different methods, personal contact, although preferable, is not an indispensable requirement. Personal documents, such as letters, diaries and biographies, photographs, and tape and video recordings, may also be a source of qualitative research (Mouton 1988:1-16). To ensure a true reflection of the points of view expressed, the completed article was submitted to all the participants either to confirm or to correct details of the views expressed.

\section{HYPOTHESES}

The following primary hypothesis functioned as the driving force for the research

There is a need for specialised information in order to maximise the effectiveness of a design for research on poverty

It has already been emphasised that the very nature and dynamics of poverty are so complicated that there is a real danger for any research on the theme to fall short in so many ways. Not dealing with the correct issues, not pushing through to the most powerful driving forces that precipitate or stimulate poverty and not working with so many important contexts and the great varieties of poverty are but three grave mistakes that could jeopardise the research and cause the outcome to be insignificant. The need for external help in planning the research was therefore apparent. The contributions of the different participants confirmed this hypothesis. The variety of points of view introduced a wide range of important perspectives and prevented the research from being incarcerated in onedimensional patterns of thought.

Two secondary hypotheses were fragmented from the main hypothesis:

a) A multidisciplinary approach is indispensable, since the phenomenon of poverty has many causes and effects. This hypothesis necessitated the inclusion of non-theologians as participators and underlined the essential need to take note of literature in scientific fields beyond theology in general and practical theology in particular.

b) If the hypothesis in a) is not implemented in a careful and responsible manner, the research could end up in a multifaceted conglomerate of ideas and perspectives from different scientific disciplines without a particular identity. Careful planning was therefore done to prevent any given scientific discipline from high-jacking the research. This article was, and the whole of the research project will be, conducted from the perspective of practical theology, using methods of research acknowledged within the field of practical theology. The research concentrates on the role that pastoral counselling can play in alleviating the many dimensions of suffering caused by poverty. It is therefore hoped that the research will ring true and come home to the grass-roots level of the church's pastoral ministry.

\section{RESEARCH GOALS}

The very nature of participatory action research determines the research goals. The participants here were therefore given the opportunity to contribute to the planning of the extensive project. The initial and preliminary design of the researcher was thus affirmed or corrected to the extent that a new and more informed design for the extensive research could be structured. This particular research therefore served as a launching article for extensive research on poverty.

\section{DIFFERENT THEMES ON POVERTY TO BE RESEARCHED}

\section{Defining poverty}

From the answers given by the participants, it is crystal clear that a definition or description of poverty is an indispensable yet almost impossible endeavour. Prof. Daniel Louw answered the question about definitions by referring to the influence of paradigms on the precipitation of poverty. How does poverty differ in post-modern societies in comparison with third-world countries? He quoted staggering statistics from India, where 250 million people out of a total population of 1.3 billion people live under the breadline, so to speak. The conclusion is apparent that different contexts influence the description of poverty and its consequences.

Prof. Cas Vos likewise expressed the importance of understanding poverty within different contexts, of which the cultural and family context plays a major role. In this sense, we may speak of a culture of poverty. Families may be caught up in this endless spiral of poverty, thereby condemning generations to a psychological spirituality of poverty ('born to be poor').

For Prof. Attie van Niekerk, the psychological aspect as determining factor for the precipitation or stimulation of poverty is of the utmost importance. The ability to combat poverty has weakened considerably during the past decades. When attempts to break the shackles of poverty are perpetually unsuccessful, the prisoners of poverty become reluctant to keep their hope 
alive. This leads to an unwillingness to be encouraged or to participate in efforts to alleviate the effects of poverty. The result is an alarming complacency that could easily lead to fatalism and a perception of 'born to be poor', thus rendering all efforts to change the status quo ineffective. August agreed with the need to describe poverty in its different forms and consequences rather than giving a definition. In this regard, he referred to the important work of Davids, Theron and Maphunye (2005). They referred to different approaches in describing poverty. These different approaches operate with different points of departure, such as developmental psychology, the basic human-needs approach, comparisons with national net income, the holistic approach (the deprivation of jobs, an income, etc.), the substanceneeds approach (the deprivation of food, clothing, housing, etc., representing the most basic needs) and the capabilities approach. According to August, the capabilities approach holds a great deal of promise, as it is assets-based. It works with the point of departure that every individual and every community have basic assets. Assets in this context refer to capabilities, talents or potential that need to be unlocked or developed. The need for a catalyst to develop the assets of people suffering from poverty offers an immense opportunity to the church.

In the same vein, Coetzee stressed the need to develop and enhance entrepreneurial abilities by developing latent skills and talents. Mentorship programmes could be the working agent for such actions of empowerment. This poses an urgent challenge to Christian leadership. The leaders of congregations should identify and utilise the great variety of knowledge and skills in their congregations and involve their congregants in such mentorship programmes. Many members of any given congregation would be eager and more than willing to help if they were only asked. Coetzee was convinced that the apparent lack of interest in congregation members to be involved could be ascribed primarily to the fact that the members with skills are never asked to be involved, thus rendering their skills, knowledge and capabilities lost to the church and to the world. Although Breed defined poverty within its many contexts and considered the many variables causing or influencing poverty, such as disease, insufficient infrastructure and natural disasters, in the final analysis, 'poverty is poverty' and it needs to be addressed. In this regard, Breed referred to the introduction to the Constitution of the Republic of South Africa, Act 108 of 1996, stating that it is the responsibility of this constitution to improve the quality of life of all citizens and to unlock the potential of all people. Breed also referred to the three indicators for poverty given by the World Bank, namely

- extreme poverty, where the income per person is $\$ 1$ per day;

- moderate poverty, where the income per person is $\$ 2$ per day; and

- relative poverty, where only the basic needs for survival are found.

An interesting and most important perspective was added to the above by Breed, who referred to the category of 'indigent poverty'. From Constitutional laws, he quoted 'indigent' to mean 'lacking the necessities of life', which includes matters such as sufficient water, basic sanitation, refuse removal in denser settlements, environmental health, basic energy resources, health care, housing, food and clothing. The quote concludes: 'Anyone who does not have access to these goods and services is considered indigent'. Many of the local governments in our country have such policies in place, yet the situation of poverty seems to worsen.

For the researcher, it is evident that the many contexts, aspects and variables of the phenomenon of poverty should be investigated and described to put in place at least a workable concept to operate with in dealing with poverty. It is envisaged that the ongoing research will focus primarily on a contextual understanding of poverty, rather than attempting to give a fixed definition. This could include the context of HIV and AIDS and its relatedness to poverty (Magezi 2007:39), cultural world views (Magezi 2007:31-38) and political and economic ideologies. In this regard, the research will focus primarily on the context of South Africa, while the broader context of world views, politics and economy will inevitably have to be considered.

\section{Political and economic ideologies}

Paradigms influence economic policies that have an effect on the creation or stimulation of poverty. The implication of this point of departure is that the broader research project should take note of economic policies and their influence on poverty. Louw preferred the term 'pastoral philosophy' to indicate the need for a critical analysis of ideologies that determines people's destiny and quality of life. August not only agreed but also expressed his conviction more prolifically. Referring to publications by Perlas (2000), Duchtrow (1998), Nurenberger (1999), Todaro (1991) and Castels $(1996 ; 1997)$, he was adamant that the extensive research should take note of world ideologies that influence economic policies as reflected in World Bank activities, UNESCO and the G8.

The need to contextualise the problem of poverty does, of course, imply that relevant South African policies should also be scrutinised. In answer to the question of political influences in the enhancement of a culture of poverty, Vos was of the opinion that a critical evaluation of the history of South Africa would be an indispensable exercise. Governmental policies of the past (apartheid) and the present (affirmative action) have had a marked influence on the creation of a culture of poverty. Van Niekerk openly rejected affirmative action as a means to combat poverty and preferred broad-based black economic empowerment as the only just and effective alternative. Vos, who found affirmative action acceptable only on the condition that it be applied in such a manner that particular groups would not automatically be disadvantaged, concurred with this.

From these remarks, it should be clear that we must learn from history so that the mistakes of the past are not continued or repeated. Coetzee, however, expressed concern for the fact that, despite the new policies of our democratically elected government, there is no marked improvement in the alleviation of poverty. This troublesome picture is further darkened by the fact that greater investment since 1994 and the creation of job opportunities for skilled workers (non-skilled workers do not benefit much) are not having any significant impact on the worsening situation of poverty in our country. The levels of poverty have, in fact, been inhibited by only $2-3 \%$ up to now. In critical reflection, Coetzee was alarmed by the inability for social and economic sustainability to be upheld and identified matters that contribute to the worsening situation in our country. The serious deterioration in basic service by local governments, systems and structures, which have come under serious pressure, and the loss of knowledge and skills via emigration are all contributing factors that weaken efforts to combat poverty.

Added to this, Van Niekerk was of the opinion that the policies that the democratic government has applied since 1994 could have a more positive result were it not for the fact that these laws have created a spirituality of indifference. People now feel that poverty is the responsibility of the government and that it is no longer their problem. They have consequently started to focus on enriching themselves. Sadly, people enriching themselves at the cost of the poor do not realise that a worsening scenario of poverty in the country will inevitably catch up with them and that they, too, will suffer.

Furthermore, Coetzee quoted his mentor, Prof. Sadi, saying that any country with an unemployment rate of $6 \%$ or more could be considered to be in trouble. South Africa already finds itself in this position, while the unemployment rate in Europe has risen to $5 \%$. This situation is doomed to worsen. At the time of the conversation with Coetzee, on 27 January 2009, the Business Day 
was reported to calculate that 310000 workers would probably be laid off during 2009. Coetzee pointed out that this is only the beginning, since a worsening of economic dispensations could lead to more job losses. According to economists, an economic recession comes in three phases. South Africa (at the time of the conversation) was experiencing only the first phase!

Although it makes perfect academic sense to revisit our history, it is not a simple matter to deal with. It should be remembered that the theme of economic ideologies and development does not fall within the boundaries of theology; neither do we have the knowledge to assess the consequences. In an interdisciplinary approach, the results of such economic policies and ideologies should be interpreted from the perspective of theology in general and of pastoral counselling in particular. A meta-theoretical approach to research in practical theology is well within the research methodology chosen for the extensive research

All these views on political and economic ideologies have such exciting potential, yet it remains an immense challenge to the church to respect boundaries and to remain true to the very nature of the church. Vos added another dimension to the problem by warning that such investigation of history should be careful not to give the impression of siding with particular political agendas or with the ideologies of particular labour unions.

\section{Role of the church}

A link between information on economic development and on poverty, on the one hand, and the opportunities offered by pastoral counselling to participate in this field of empowerment, on the other hand, has to be found. According to Breed, such bridging developmental agencies (and structures) do exist; the Gauteng Developmental Agency and the Industrial Development Corporation $^{1}$ are but two of these. The church, however, has neglected the theme of poverty in its preaching, according to Vos, while important biblical concepts, such as sjalom and tzedekia, as vehicles for making congregation members aware of the many challenges of poverty have been left untouched.

The question on the role that the church could play in fighting poverty was answered dialectically by Breed. He asked whether 'church' in the question should not be substituted by 'society'. This could give the impression that it is not the church's responsibility - which is clearly not what he meant, since he was referring to the biblical principles that form the basis of the church's responsibility. What was meant is that, since the church does not have all the infrastructure to be effective in its plight to help to combat poverty, it would have to liaise with society and existing infrastructure to make its efforts more effective, a point reiterated by the other participants in the research.

This means active involvement with society; getting hands dirty, metaphorically speaking. The culture of caring from a distance by merely giving money should be changed and church members should be encouraged and trained to be actively involved. August described the church as 'wounded healer' and referred to the example of Christ becoming a servant (Phlp 2). He quoted Burkey (1996) in this regard: 'Go to the people, live with them, love them, learn from them, work with them, start with what they have, and build on what they know'.

When poverty is given a face, the need and the urgency will ring clear in the minds and hearts of church members (Vos). More publicity should be given to both needs and actions to create greater awareness, Breed felt. When this awareness sets in, careful planning should be done to prevent the duplication of sustaining efforts, which Breed felt was already happening all too often.

A narrative approach could help us to establish solidarity with the plight of the poor (Coetzee). Where structures for addressing

1.A special unit for the purpose of generating funds for projects. the many needs of poverty do not exist, the church should take the initiative by starting such structures and projects. This implies the need for a 'public theology', which could also be described as a missional diaconia, said Vos. Breed refers to the moral fabric of society to empower the rich to help the poor and the poor to sustain the poor, help being offered across cultural boundaries. Some local governments, such as the Emthanjeni Municipality (De Aar, Hanover and Britstown), have made large areas available for agricultural and subsistence purposes for the poor, known as Commonage Projects and comparable with the so-called Green Revolution in India, said Breed.

This concurs with Coetzee's view, who urged the church and its members to become actively involved in the activities of existing structures to make a significant contribution. In the words of Magezi, apathy should be changed to empathy (Magezi 2007:8). Coetzee stressed the point that the church simply does not have the ability to make a marked difference on its own, since the inherent problems precipitating and feeding poverty are multidimensional. There is so much that the church could do, however, in terms of education, training and so on, if the leaders and members of the church were to seize the opportunity to work together with existing organisations and structures. Synergy with local government is essential. According to Coetzee, this could include the improvement of services, such as the availability of clean water, effective sanitation and the creation of job opportunities. Regarding the last-mentioned, Coetzee considered the possibility of involving poor people in public services, such as building and repairing roads and building houses.

It seems as though there is a perfect opportunity for the church to respond to the need of the moment, to rise to the occasion, so to speak. Van Niekerk referred to research being done by Blair (2005) on poverty in Africa, where it has been found that the people of Africa are disillusioned with political ideologies and structures and no longer believe that politicians can save them from poverty. They are therefore turning to religion and the church to find hope and help again. If this assumption is correct, then the time for the church to become relevant and become a major role-player has never been better. If this is to happen, however, the church will have to change its strategy. According to Van Niekerk, dialogue within the church is not effective enough. Congregations should be motivated to engage in meaningful discourse by listening to narratives from the poor community in order to understand the urgent need. Only then will the church be empowered and motivated to become a partner with poor communities to strategise joint efforts in combating a common enemy. In order to do this, the church should engage in discourses on an alternative lifestyle, thereby addressing the restless pursuit of wealth and luxury; the destructive forces of a consumer's mentality should be exchanged for a sober Christian lifestyle.

\section{Reviewing and assessing the participatory action research}

The marked characteristic of this research is that the points of view of the different participators not only agree in all major aspects but also interrelate with each other to such an extent that theories are extended, thus enabling the development or extension of basis and practical theories. Revisiting the convictions expressed, the following brief conclusions are made in view of the continuation of the broad research that is to follow:

\section{Defining poverty}

Although it is important to profile the major concepts in this research, it seems to be a futile pursuit to try to define poverty. All the participants agreed that poverty has too many faces, causes and consequences to try and capture it all in one definition. Louw illustrated this very effectively by explaining that a conversation with a so-called bergie (an alcoholic who begs for money and 
food) is totally different from a conversation with an empowered and learned person who has lost her or his job because of retrenchment. Efforts to describe poverty from different vantage points, as illustrated by Davids et al. (2005), seem to be troublesome in themselves, since they could end up describing causes, effects or remedies (in other words, the capabilities approach) rather than working towards a definition. Although these are all extremely important in dealing with poverty and will most definitely be examined in the future research, this would be in an attempt to describe and analyse poverty rather than defining it. In this regard, the most important determining factor should probably be the many different contexts within which poverty develops and thrives. Understanding the context helps to understand the nature of poverty for those particular sufferers in that particular situation.

\section{Context of the research}

The context of the planned research will be Africa in general and South Africa in particular. It is not, of course, possible to isolate the poverty in Africa from the poverty in the rest of the world. There are too many common denominators in the phenomenon to limit the research to the relevant literature and issues of Africa. Perlas (2000) explained the context of globalisation and the phrase 'global and local' has developed into the coining of the word 'glocal'. And, indeed, much can be learnt from other contexts and what is being done in those situations. When Louw, for example, referred to the terrible situation in India, he used Mother Teresa as an example of a humanitarian approach to be followed; she did not merely work with some action plan to combat poverty but she went to the people merely to be with them. The impact of this example is well known throughout the world, and not taking notice of such lessons would leave the research all the poorer. There must be many other lessons that we can learn from.

\section{Paradigms and ideologies}

One of the most daunting tasks of the research seems to be the understanding of paradigms and ideologies in the precipitation and worsening of poverty. Louw's concept of a pastoral philosophy is relevant here. It has been clearly illustrated how political agendas have influenced destructive processes in the South African context. Research of this nature, taking a pastoral theological point of departure, could hardly be informed enough to evaluate political programmes. Furthermore, an approach that does not respect the boundaries of different disciplines could easily go astray and lose its theological character. However, this does not mean that the matter of ideologies and paradigms is out of bounds. Theology in general and practical theology in particular could and indeed should be able to evaluate such matters in terms of their effect on societies, cultures and individuals. Using an interdisciplinary approach, the knowledge of experts in their own field will therefore be used. All the participants agreed that a study without attending to the matter of paradigms and ideologies would render such research irrelevant and fruitless. The warning that we should be careful not to side with particular political parties will also be heeded but the need to be just but radical in evaluating policies will have to be pursued vigorously. This brings us to the next marker for the research.

\section{Prophetic task of the church}

For too long, the church has not contributed enough in terms of combating poverty. Many churches, for example, remained silent when they should have spoken out against the atrocities of apartheid. The church (including all denominations) certainly did much to alleviate the suffering of the poor but this was more focused on Christian charity and not really on substantial and structural efforts to combat poverty. Furthermore, where significant efforts came from individual theologians and researchers, they did not always receive attention from the church. I am of the opinion that the prophetic task of the church should function much more in the current political and social dispensation of South Africa. The radical condemnation of king and country during the times of the prophets should again be bravely pursued. Isaiah and Amos (to mention but two) did not refrain from relating unjust conduct towards the poor and the marginalised with a rejection of God's compassion. God's wrath and judgement were proclaimed. This could, of course, precipitate the wrath of political and even church leaders but the urgency of the matter demands nothing less. Examples to be followed do exist (such as in Theron's report). August's understanding of a pastoral anthropology, including the matter of sin and the responsibility to reprimand when needed, could be seen as part of the prophetic task. In many cases, there are indeed links between people's situation of poverty and the sinful lifestyle that influences that situation. Such examples should be investigated and pastoral remedies should be pursued.

\section{Humaneness (ubuntu) as goal}

Besides agreeing on the prophetic task, all the participants also agreed that the church has a significant and indispensable role to play in changing the destiny of people. The early work of the systematic theologian Lehmann is very relevant here. He described the task of Christian ethics as 'making and keeping human life human'. This has definite political implications for the church: 'In the koinonia the will of God is no pious platitude but a clear and concrete matter of politics. In short, "the God of the Church" is "the God of politics"' (Lehmann 1976:82). August was therefore correct in identifying the focus of the church as human centredness (or humaneness). The important work by August (2005) dealt directly with this issue and will be the first to be consulted in further work. I am particularly interested in the consequences of August's point of view in that the peoplefirst approach implies that respect for the culture of the people to be helped is extremely important. An approach that merely criticises and subsequently breaks down third-world culture would be unproductive, since it would be viewed by certain cultures as insensitive, arrogant and unacceptable. Louw likewise spoke of community pastoral care. He identified the task of the church as God-founded and human-centred, using the terms 'centripetal' and 'centrifugal' to illustrate the principle (Louw 1997:89). He emphasised the principle of hope and saw the church as the conveyer of such hope. Although he did not really make an issue of the principle of hope in the hour-long discussion, he is renowned for his eschatological proprium for pastoral care. August concurred with Louw, explaining in the same vein as Louw's eschatology that both the eternal and the earthly consequences of God's Kingdom should be included in the principle of hope, covering both the here and now of the manifestations of the Kingdom to be pursued by the church and the 'not yet' of things to come. Eschatology and hope will therefore play a predominant role in the theological basis theory for pastoral care and poverty. In this regard, I am excited about August's remark that a theology of hope would lead to the courage to be, thus precipitating the will to take up personal responsibility.

\section{Holistic approach}

If the church is to play this designated role, a shift in paradigm is needed. The church will have to see its task within a much broader responsibility than merely adhering to preaching and traditional pastoral care for the poor. I have found immense inspiration from the views expressed by the participants on practical ways to be involved in order to make a difference. These include using existing structures both within and outside the church, creating structures where they do not exist, liaising with government and undertaking interdenominational actions. It is clear and it has been emphasised that the church will not be able to be a significant role-player on its own. This is probably one of the major reasons why efforts by the church in the past have not nearly been as successful as hoped. In this regard, I was impressed by the finding of Blair (2005) that poor people are disillusioned by politicians and policies and are now turning to the church for hope and help. This offers both a unique 
opportunity - not to be missed again - and an immense challenge to the church. While revisiting these examples of the many possibilities offered to the church, I could not help but wonder if the move of some congregations from a denominational link to a community-based church was influenced by the insight of their church leaders into the charge of the church and what is urgently needed to facilitate this. The motives and functioning of such community churches will therefore be investigated in order to learn from them. Does such a move, for example, open up more possibilities for funding and support from the private sector, since it is possible that organisations in the private sector would be hesitant to support one particular denomination? I am also aware of other church projects and publications similar to those of Burger, Meiring, Van Niekerk and Wepener (2005; see also BUVTON 2002; Nel 2006). Such publications will be thoroughly scrutinised for possible markers in methodology and results.

\section{Empowerment}

The driving force behind the church's involvement would be primarily the need for empowerment. Since this term is loaded with political intention and many congregation members instinctively resent the political connotation to a theology of revolution, a clear understanding of what is understood by empowerment within the context of the church's action would be necessary. Some of the participants in this research used alternative words, such as mentorship, leadership and the church acting as catalyst for processes of change and healing.

I believe in the matter of empowerment, with its many possibilities of being at the core of the church's responsibilities. This need was again imprinted on my mind when one of the participants in a discussion on poverty for Radio Pulpit rejected research on poverty outright, saying that there is no more time for research. Instead, she identified the church's responsibility as giving hand-outs of bread and milk.

This probably reflects the lack of knowledge and understanding of the problem of poverty as the most threatening aspect jeopardising the efforts of the church. Without structured actions of empowerment to help people to overcome their predicament, we would simply lose face and effectiveness if we adhere merely to handouts. Of course, as Van Niekerk warned, such financial aid, food supply and material support should not be stopped but rather increased. At this stage, however, given the seriousness and urgency of the problem, we need to look further and dig deeper, not only to find means and create structures but also to work towards preventative action.

This makes the church's responsibility so much more daunting. In this regard, I feel the need to investigate ways and means of effective empowerment in order to prevent what Breed referred to as ineffective training, leaving trained people in a state of unawareness of their potential and capabilities. This means that training fails to empower people to apply their training to their personal needs and context and to better their capabilities and circumstances.

\section{Personal involvement}

Since much has been made of the need to be personally involved with the plight of the poor and since the narratives of sufferers have been identified as a medium to achieve this, it is envisaged that a qualitative cross-section analysis would be one of the much-needed projects for the future research. Careful planning and the possible limiting of the cross-section choice, however would be indispensable in attaining some cohesion. After all, there are so many thousands of sufferers. How do you choose a cross-section and according to which guidelines? The goals of this type of research will therefore have to be identified carefully to prevent an unsystematic parading of sufferers.

\section{Extended view of pastoral care and counselling}

All the comments on the nature of poverty necessitate an extension of perceptions on pastoral care. In this regard, the question of whether we can afford the luxury of clinging to fixed definitions of pastoral care, counselling and therapy arises. If the church is to be an effective agent of hope, not just for eternal life but also for this life (Coetzee), and if pastoral care is to be seen as an agent of hope within the context of the Kingdom of God, we will most definitely have to revisit our own ideologies and methodologies. In this regard, Van Niekerk championed a more pragmatic approach. Congregations will have to be empowered to analyse social patterns within a community if they are to empower the community in turn. This includes the responsibility not just to focus on trying to break the vicious cycle of violence but also to take prophylactic measures. Children's nursery schools could, for example, be a point of departure to inform, motivate and train children to become aware of the possibilities of a better life, according to Van Niekerk.

The traditional understanding of pastoral counselling will therefore have to be revisited, for we can no longer adhere to the basics of pastoral counselling (care, counselling and therapy) if we are to be involved significantly in searching for effective strategies to combat poverty. The view of De Klerk (1978) that we need to make a distinction between Christian charity and pastoral care is theologically correct. It is, however, a theoretical distinction that, in the past, has caused an unacceptable divide between the two theological disciplines. It offers a luxury that we can no longer afford. Further investigation is envisaged, which would have to include the implications of the definition given to pastoral counselling by exponents such as Hiltner, Heitink and Louw.

Magezi (2007:3) expressed the same sentiments: 'In order to provide a support system to people suffering from HIV / AIDS within a poor community setting, the pastoral ministry should move away from a very sophisticated counseling room approach to a congregational systems approach, which is focused not only on the congregation but also on the needs, pain and suffering of the community and society'. Van Niekerk likewise wanted pastoral counselling to go further than spiritual counselling. Pastoral advice could include the sharing of knowledge and skills, fund-raising and liaising with existing networks. This matter will receive extensive attention in the research article on pastoral care and poverty that is to follow.

\section{Psychological dimensions of poverty}

From the moment that I started researching the phenomenon of poverty, I was interested in the psychological aspects of suffering within a poverty-stricken context. Myers (1999:100-101) used the term 'entrapment' to indicate the many aspects contributing to a situation without apparent escape. The psychological aspect seems to be one of the most important. When asking the participants about this, my anticipation about this matter was confirmed. Aspects that came to the fore were the psychological influences on personality within a poverty-stricken context, the possibility of low self-esteem and the consequent drawbacks, and the preconditioning to accept the situation of poverty passively, giving up all hope and relinquishing all effort to change one's destiny. I anticipate that this aspect will be an important one to focus on and that a separate article will be needed to attend to this matter, again not from a perspective of psychology (this has already been done by other researchers, such as Carr \& Shoan [2003]) but from a perspective of pastoral theology. What can the pastoral counsellor offer to assist people with such a psychological drawback? Can pastoral care and counselling develop inner healing and stimulate an internal (endogenous) process of personal growth and confidence? The work by Castels (1997) will be relevant in this regard. This brings us to another matter.

\section{Pastoral anthropology}

Revisiting the contributions of the participants, the importance of pastoral anthropology came under discussion as an indispensable part of a basis theory for pastoral care and poverty. This theme 
is such a core issue in the pastoral theology of Louw that he dedicated a large part of his many publications to this issue (1997; 1999; 2005; 2008). In my own approach, I am particularly interested in the link and interaction between anthropology and Christology. I refer not merely to a Christ-centred approach, as does August, or to a Trinitarian approach (Burkey 1996:38) but intend to investigate the pastoral implications of Christology for anthropology in general and for the poverty-stricken man in particular, giving attention to aspects such as the kenosis of Christ and the relevant issues of solidarity, compassion, salvation and healing, which can be derived from this. Also, the point of departure of Clinebell, as seen in John 10:10 (1987:51), would naturally be part of such a Christological approach. An abundant life concurs with what Louw terms 'existential meaning in existence'. The contribution of systematic theology will also be utilised and applied to the pastoral context.

\section{CONCLUSION}

The decision to utilise the knowledge and experience of experts in a participatory action research proved to be a fruitful endeavour. Many basic issues that will now be thoroughly investigated in the extensive research project were identified. It is hoped that the contribution of my specific research from the perspective of pastoral care and counselling will highlight the theological dimensions and practical implications left untouched until now.

\section{ACKNOWLEDGEMENT}

This research is being done with a grant from the National Research Fund.

\section{REFERENCES}

August, K.T., 2005, The quest for being public church, Moravian Printing Works, Cape Town.

Babbie, E., 1998, The practice of social research, Wadsworth Publishing Co., Albany.

Blair, T., 2005, Commission for Africa. Our common interest. An argument. Report of the Commission for Africa. Penguin Books, London.

Bothma, J.D., 2003, 'Pastorale terapie met die MIV/VIGS geaffekteerde familie: 'n Narratiewe benadering', Doctoral dissertation, University of the Free State, Bloemfontein.

Burger, C., Meiring, L., Van Niekerk, A. \& Wepener, C., 2005, Waar die kerk werk, Lux Verbi, Wellington.

Burkey, S., 1996, People first, Zed Books, London.

BUVTON, 2002, Raak betrokke by armoede. 'n Handleiding vir gemeentes en kleingroepe, Lux Verbi, Paarl.

Carr, S.C. \& Shoan, T.S., 2003, Poverty and psychology, Kluwer Academic, New York.

Castels, M., 1996, The rise of network society, Blackwell, Oxford.

Castels, M., 1997, The power of identity, Blackwell, Oxford.

Clinebell, H., 1987, Basic types of pastoral care and counseling, Abingdon Press, Nashville.

Couture, P.D., 2003, Poverty, suffering and HIV-Aids, Cardiff Academic Press, Cardiff.

Davids, I., Theron, F. \& Maphunye, K.J., 2005, Participatory development in South Africa, Van Schaik, Pretoria.

De Klerk, J.J., 1978, Herderkunde, NG Kerkboekhandel, Pretoria.

Duchtrow, U., 1998, Alternatives to global capitalism, Kairos/ Kaiser Verlag, Heidelberg.

Lehmann, P.L., 1976, Ethics in a Christian context, Harper \& Row, New York.

Louw, D.J., 1997, Pastoraat as vertolking en ontmoeting, Lux Verbi, Kaapstad.

Louw, D.J., 1999, A mature faith. Spiritual direction and anthropology in a theology of pastoral care and counseling. Theological $\mathcal{E}$ pastoral monographs 25, Peeters Press, Louvain.

Louw, D.J., 2005, Ratwerke van die menslike siel. Oor volwassenheid en lewensvaardighede, Stellenbosch University Press, Stellenbosch.
Louw, D.J., 2008, Cura Vitae. Illness and the healing of life, Lux Verbi, Wellington.

Magezi, V., 2007, HIV/AIDS. Poverty and pastoral care and counseling, Stellenbosch University Press, Stellenbosch.

Mouton, J., 1988, 'The philosophy of qualitative research', in M. Ferreira \& J. Mouton, Introduction to qualitative research, Module 3, pp. 1-16, Human Sciences Research Council, Pretoria.

Mouton, J. \& Marais, H.C., 1989, Metodologie van die geesteswetenskappe: Basiese begrippe, J.C. Insto-Print, Pretoria.

Myers, B.L., 1999, Walking with the poor, Orbis Books, New York.

Nel, M., 2006, Stories van hoop, Christelike Uitgewers Maatskappy, Vereeniging.

Nurenberger, K., 1999, Prosperity, poverty and pollution, Zed Books Ltd, London.

Perlas, N., 2000, Shaping globalization, Falcon Press, Cape Town.

Smith, K.G., 2008, Academic writing and theological research, S.A. Theological Seminary Press, Johannesburg.

Todaro, M.P., 1991, Economic development in the Third World, Longman House, Harlow.

\section{ADDENDUM A}

\section{PARTICIPANTS IN THE PARTICIPATORY ACTION RESEARCH}

\section{Attie van Niekerk}

Prof. Van Niekerk was born on 6 April 1951. He has been director of the Nova Institute since March 1994 (seconded by the Transvaal Synods of the NG Church as tent-maker minister) director of the Institute for Missiological and Ecumenical Research and a part-time senior lecturer in the Department of Religion and Missiology at the University of Pretoria. The Nova Institute focuses on research and development with the aim of finding solutions to improve the quality of life of low-income households in the African context. It works closely with churches but also with industry and government departments.

\section{Daniël Louw}

Prof. Louw is responsible for Practical Theology in general and Pastoral Theology and Counselling in particular at Stellenbosch University. He was part of a research team and was project researcher on the theme of poverty. This research culminated in a publication on poverty. He also contributed to a research publication on poverty, Poverty, suffering and HIV-AIDS (Couture, Millert \& McLemore 2003) by the International Academy for Practical Theology. He is an acknowledged researcher of high standard.

\section{Kallie August}

Prof. August is head of the Department of Practical Theology and Missiology, University of Stellenbosch.. He is also coordinator of the Division for Theology and Development Studies in the Department. His doctoral dissertation, Public church studies (2003), and his knowledge and experience in the field of poverty have equipped him with amazing skills to make a significant contribution to the research on poverty.

\section{Cas Vos}

Prof. Vos is dean of the Faculty of Theology, University of Pretoria. He is an established and acknowledged researcher, with many academic accolades, and a leader in the field of research in practical theology. Of particular interest are his contribution towards determining the theme of hope in preaching during the world conference of the Societas Homiletica in South Africa and his contribution to the resulting publication under the title Preaching as a language of hope (Vos, Hogan \& Cilliers 2007).

\section{Stef Coetzee}

Prof. Coetzee completed an MA (1974) and DPhil (1980) in economics. He also completed the Strategic Leadership Program 
at Templeton College, Oxford, in 2000. His career can be divided into four phases:

- He became known as a development economist, first as an academic at the University of the Free State and the University of South Africa and then at the Development Bank of Southern Africa and as head of the Africa Institute of South Africa.

- In a surprising move to himself, he then entered the field of higher education as vice-rector responsible for research development at the then University of Potchefstroom for Christian Higher Education (1994-1996) and, from 1997 to 2002, as rector and vice-chancellor of the University of the Free State, where he successfully led transformation and financial turnaround programmes, for which he received the Centenary Medal from the University of the Free State in 2004 .

- He used the above-mentioned experience in the third phase of his career to lecture in change management, leadership and sustainable business in poor communities at the Stellenbosch University Business School (USB) (2003-2007), where he was advisor to the CEO of NEPAD, became director of the South African Learning Laboratory on doing business at the bottom of the income pyramid and represented the USB as member of the Globally Responsible Leadership Initiative.

- This subsequently led to his appointment as executive director of the Afrikaanse Handelsinstituut (AHI) (an organised business movement) from 1 October 2007, where he plays a leadership role in the organised business sector of SA. The strategic agenda of the AHI includes the base of the pyramid learning laboratory (in other words, doing business in poor communities), a black empowerment trust and a partnership with the Department of Provincial and Loca Government on local government issues and local economic development.

\section{Johann Breed}

Johann Breed is a local government management consultant for the Amatenda Group of Companies. He is particularly guided by the prayer of Psalm 25: 4-5 (a prayer for the guidance of God) and by existential psychology in general and Viktor E. Frankl in particular. He is currently busy with research on the theme 'Beyond local government'. His focus is local economic development. He has done extended research in this field and has had extensive experience, which makes him an important contributor to the participatory action research. 